\title{
Identification of marine fish egg predators using molecular probes
}

\author{
Clive J. Fox ${ }^{1, *}$, Martin I. Taylor ${ }^{2}$, Jeroen van der Kooij ${ }^{3}$, Natasha Taylor ${ }^{3}$, \\ Stephen P. Milligan ${ }^{3}$, Aitor Albaina ${ }^{4}$, Sonia Pascoal ${ }^{2}$, Delphine Lallias ${ }^{2}$, \\ Marjorie Maillard ${ }^{2}$, Ewan Hunter ${ }^{3}$
}

\author{
${ }^{1}$ Scottish Marine Institute, Scottish Association for Marine Science, Oban PA37 1QA, UK \\ ${ }^{2}$ Molecular Ecology and Fisheries Genetics Laboratory, ECW Building, School of Biological Sciences, \\ Bangor University, Bangor LL57 2UW, UK \\ ${ }^{3}$ Centre for Environment, Fisheries and Aquaculture Science, Pakefield Road, Lowestoft, Suffolk NR33 OHT, UK \\ ${ }^{4}$ Laboratory of Genetics, Department of Genetics, Physical Anthropology \& Animal Physiology, \\ Basque Country University, Leioa 48940, Spain
}

\begin{abstract}
Mortality during the egg and larval stages is thought to play a major role in determining year-class strength of many marine fish. Predation of eggs and larvae is normally considered to be a major factor but the full suite of predators responsible has rarely been identified. Potential predators on a patch of plaice Pleuronectes platessa eggs located in the eastern Irish Sea were mapped using acoustics and sampled by trawl and a plankton multi-net. Gut contents of 3373 fish, crustacea and cephalopods sampled in the area were screened using a plaice-specific TaqMan DNA probe. Herring Clupea harengus and sprat Sprattus sprattus dominated trawl catches and showed high positive TaqMan responses $(77$ and $75 \%$ of individuals tested respectively). Locations of clupeid schools also broadly corresponded with the distribution of fish eggs in the plankton. Whiting Merlangius merlangus were also reasonably abundant in trawl hauls and $86 \%$ of their stomachs tested positive for plaice DNA. Species showing lower levels of positive TaqMan response included mackerel Scomber scombrus, poor cod Trisopterus minutus, squid Loligo spp., dogfish Scyliorhinus canicula and weever Trachinus vipera. Nonreactivity of all negative controls precluded the occurrence of cross-contamination, and positive reactions from demersal species, such as dogfish and weever, may have resulted from secondary predation. No benthic macro-crustaceans tested positive. Samples of planktonic organisms yielded $13 \%$ positive TaqMan reactions, mainly from clupeoid or sandeel (Ammodytidae) larvae, but also included some Malacostraca and Amphipoda. Use of the molecular approach allowed rapid screening of a large number of potential predators of plaice eggs, and the results provide a more holistic description of the predator community than has previously been achieved.
\end{abstract}

KEY WORDS: Herring $\cdot$ Sprat $\cdot$ Predation $\cdot$ Fish eggs $\cdot$ Plaice $\cdot$ Recruitment Resale or republication not permitted without written consent of the publisher

\section{INTRODUCTION}

Despite over 100 years of research, our understanding of the processes involved in controlling year-class strength in marine fish is still limited (Houde 2002, 2008, Platt et al. 2007, Zhang et al. 2010, Fässler et al. 2011). Since Hjort's critical period hypothesis Hjort (1914), which invoked the onset of larval feeding as the crucial stage, there has been considerable debate about when year-class strength is determined. The current consensus is that it varies with species and stock (Myers \& Cadigan 1993, Houde 2008) but there are examples where yearclass strength appears to be set at a very early stage. 
In the southern North Sea, year-class strength of plaice Pleuronectes platessa is predictable from the abundance of Stage V eggs (Bannister et al. 1974, Harding et al. 1978, Brander \& Houghton 1982), and for herring Clupea harengus in the northern North Sea, mortality during the first $30 \mathrm{~d}$ of larval life appears critical (Fässler et al. 2011). Further research into the causes of egg and larval mortality should therefore contribute to a better understanding of the conditions which generate periods of good and poor recruitment, at least for some species and stocks (Fässler et al. 2011, Huwer et al. 2011).

Although embryonic malformations (Cameron \& von Westernhagen 1997), disease and parasites (Meneses et al. 2003), and exposure to ultra-violet radiation (Browman 2003) and pollutants (Klumpp \& von Westernhagen 1995, Cameron \& von Westernhagen 1997) can all kill fish eggs, predation is generally thought to be the main cause of egg mortality (Hunter 1981, Sissenwine 1984, McGurk 1986, Bunn et al. 2000). Despite its supposed importance, there are relatively few field studies on predation of fish eggs (Heath 1992, Houde 2008). Because prey are often digested rapidly, identifying items from predator stomach contents can be difficult (Heath 1992). Rapid digestion is a particular problem with regard to larval fish as prey (Folkvord 1993), but the chorions of eggs are generally more resistant to digestion. Egg shells in stomachs may, however, be difficult to assign to species, unless they possess visually distinct external characteristics (Russell 1976, Hunter \& Kimbrell 1980, Brewer et al. 1984, Ellis \& Nash 1997). Many of the studies that have been conducted have concentrated on the role of fish as predators, but fish eggs (and larvae) are exposed to a wide spectrum of other potential predators including chaetognaths (Feigenbaum \& Maris 1984), gelatinous zooplankton (Purcell 1985, Lynam et al. 2005), euphausiids (Theilacker et al. 1993, Krautz et al. 2007) and some of the larger copepods. Obtaining direct visual evidence of consumption from some of these groups, particularly the crustacea, is difficult as they macerate their prey (Theilacker et al. 1993, Taylor \& Danila 2005). Finally, visual gut content analysis is a relatively labour-intensive and timeconsuming procedure.

Recently, molecular methods have provided additional tools for predation research. Several studies have successfully applied immunological assays to detect predation in the marine environment (Theilacker et al. 1986, 1993, Krautz et al. 2003, Taylor 2004). This approach has certain advantages as the method can sometimes discriminate life-history stages, e.g. by detecting the presence of yolk proteins (Theilacker et al. 1986, Taylor \& Danila 2005). There are also claims that detection times in the presence of digestion may exceed DNA-based methods (Symondson 2002). On the other hand, immunoassays are expensive and difficult to develop and may not be replicable between laboratories. DNA-based methods are therefore becoming increasingly used. In this approach, either a taxon-specific DNA-probe is developed (e.g. Taylor et al. 2002) or cloning or pyro-sequencing are used to evaluate the presence of a broader range of taxa using DNA sequences (e.g. Cytochrome Oxidase I [COI] barcodes). Both probing and sequencing techniques include DNA amplification and can be applied to very small quantities of target DNA. In order to improve the chances of successful detection it is usual to target relatively short nucleotide sequences, since prey DNA becomes fragmented during digestion in the predator gut. Examples of successful applications include Rosel \& Kocher (2002), who described a polymerase-chain reaction (PCR) assay to detect cod larvae in mackerel Scomber scomber stomachs, and Nejstgaard et al. (2003) and Vestheim et al. (2005) who used similar assays for identifying prey in copepod faecal pellets. Applications using cloning or pyro-sequencing to identify multiple prey taxa include studies on the diets of seals (Deagle et al. 2009) and lobster larvae (Suzuki et al. 2008). Before any molecular method for prey detection is applied to field samples, the method's specificity against a range of potential prey must be tested. In addition, experiments are needed on the extent to which digestion of the target DNA in predator guts reduces detection rates. Given the extreme sensitivity of these methods, stringent efforts are also needed to control cross-contamination during field sampling (Symondson 2002, Passmore et al. 2006).

In previous papers we described the development of a TaqMan probe for plaice DNA, demonstrated its specificity and described the effects of digestion by crustacean and teleost predators on detection efficiency (Albaina et al. 2010, 2012, Hunter et al. 2012). Here we describe the first application of this method to study predation of plaice eggs (and larvae) in the field. Because the TaqMan assay cannot distinguish between the egg and larval stages of plaice, we refer to detection of predation on eggs/larvae throughout. In addition, we assume that consumption of adult plaice by the suite of potential predators that we assayed would not occur, or would be obvious during dissection of predator stomachs. Because plaice spawning occurs 
offshore, but nursery grounds are inshore (Fox et al. 2007), we also assume that small, juvenile plaice were not present in the study area. Although remains of plaice eggs can be visually identified in teleost stomachs (Ellis \& Nash 1997), we wanted to test the molecular approach as an alternative method for rapid screening of large numbers of potential predators and to identify any non-teleost predators consuming plaice eggs/larvae in the study area.

\section{MATERIALS AND METHODS}

\section{Field sampling}

Cruises were conducted in 2008 and 2009 on a well-described plaice spawning ground (Fox et al. 2000a, Bunn et al. 2004, Bunn \& Fox 2004) in the eastern Irish Sea (Fig. 1). In 2008, the cruise (25 February to 2 March) was affected by poor weather and focussed on developing sampling protocols and conducting an initial evaluation of the range of predators taking plaice eggs/larvae. The cruise in 2009 (19 to 28 February) included plankton sampling, to locate the egg patch, trawling and dedicated acoustic grids. In addition, a plankton multi-net (Bedford Institute of Oceanography Net and Environmental Sampling System, BIONESS, Ocean Seas Instrumentation) was deployed. Near-surface temperature and salinity were logged throughout every 5 min using an Aquatracka system (Chelsea Instruments).

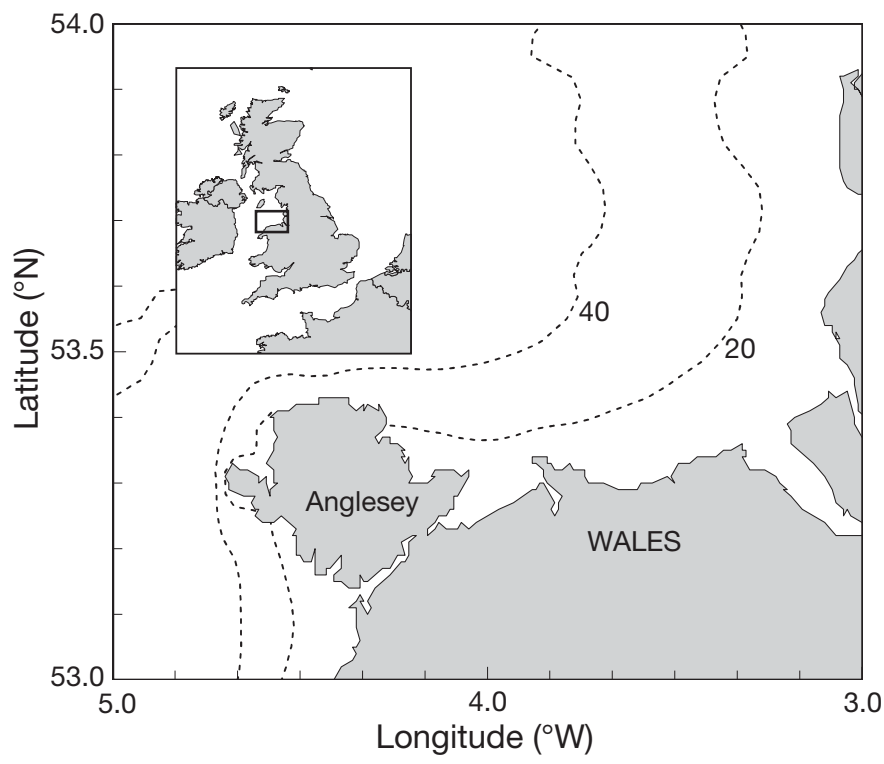

Fig. 1. Study region showing depth contours (m)

\section{Vertically integrated plankton sampling}

On both cruises, a patch of plaice eggs was identified by sampling a grid of approximately 12 plankton stations. The grid was completed at both the start and end of the 2009 cruise but only at the start of the 2008 cruise. Plankton samples were collected using a $76 \mathrm{~cm}$ Lowestoft Gulf VII high-speed sampler fitted with a $40 \mathrm{~cm}$ diameter nose-cone, $275 \mu \mathrm{m}$ mesh net and internal and external Valeport flowmeters (Nash et al. 1998). Flow data, salinity and temperature profiles were captured with a Valeport MIDAS-CTD mounted on the body of the sampler. The Gulf VII was deployed in an oblique tow from the sea surface to near the seabed and back at 3 to 4 knots. Upon recovery, the net was washed down and the contents of the cod-end fixed in $4 \%$ formalin $(4 \%$ formaldehyde in distilled water buffered with $2.5 \%$ sodium acetate trihydrate, w/v). Samples were sorted onboard for plaice eggs to gain a rapid estimation of the patch location, then subsequently re-sorted in the laboratory for all fish eggs and larvae (Russell 1976). Egg and larval numbers were expressed as numbers per $\mathrm{m}^{2}$ of sea surface using the sampled depth and the volume filtered, which was estimated from flumebased calibrations Brander et al. 1993).

\section{Acoustics}

In 2009 the distributions of pelagic fish were mapped using a Simrad EK60 split beam echosounder operating at 38, 120 and $200 \mathrm{kHz}$. The transducers were mounted on a drop keel; pulse-duration (0.512 ms), ping rate (1 s) and other operational settings followed Korneliussen et al. (2008). At the start of the survey all 3 frequencies were calibrated with the keel lowered at the operating depth ( $2 \mathrm{~m}$ below the hull), using the standard sphere method (Foote et al. 1987). A high resolution acoustic survey was undertaken consisting of a number of equidistant, parallel transects perpendicular to the coast, which covered all but the very eastern- and western-most parts of the plankton sampling area. During acoustic surveying the vessel speed was $~ 8$ knots when steaming and 4 knots whilst collecting plankton and trawling.

Acoustic data were analysed using Echoview (version 4.6; Myriax). A filter was created (sum of 3 frequencies above $-183 \mathrm{~dB}$ ) to remove all weaker scatterings using the virtual echogram module, leaving only the acoustic marks associated with fish possessing swim-bladders. A dilation filter was then applied to account for reduced beam overlap between the 
transducers at shallow depths and a final erosion filter applied to preserve the original school shape and size. The nautical area backscattering coefficient (NASC, $\mathrm{s}_{\mathrm{A}}, \mathrm{m}^{2}$ nautical mile ${ }^{-2}$ ) was exported and the catch composition from the trawl hauls used to partition the $\mathrm{s}_{\mathrm{A}}$ into species-specific contributions. Length-weight relationships of sprat Sprattus sprattus and herring were also obtained from the trawl data and used with length-dependent target strength (TS) measurements from the literature $\left(b_{20}=-69.1 \mathrm{~dB}\right.$ for sprat, Robinson 1983 and $-72.1 \mathrm{~dB}$ for herring, Foote 1987) to convert the $\mathrm{s}_{\mathrm{A}}$ into estimates of abundance and biomass.

\section{Trawling}

For fish sampling in 2008 we used a Portuguese high-headline trawl (PHHT; Cosalt) and in 2009 this was supplemented with a sandeel trawl and a $4 \mathrm{~m}$ beam trawl in order to sample a wider range of species. Tow durations with the PHHT varied between 15 and $30 \mathrm{~min}$ but were up to $50 \mathrm{~min}$ with the sandeel trawl. The PHHT had a wing-end spread of $22.5 \mathrm{~m}, 140 \mathrm{~mm}$ mesh in the wings and throat and $135 \mathrm{~mm}$ mesh in the cod-end, with a $20 \mathrm{~mm}$ mesh liner. The wing-end spread of the sandeel trawl was $20 \mathrm{~m}$ and the mesh varied from $800 \mathrm{~mm}$ at the mouth to $120 \mathrm{~mm}$ at the cod-end, which had a $10 \mathrm{~mm}$ mesh liner. Tows were conducted at approximately 4-hourly intervals over periods of 2 to $3 \mathrm{~d}$. Catches were sorted into species and the total weight of each species and individual total lengths of fish recorded (to the nearest 0.5 or $1 \mathrm{~cm}$ interval below following ICES International Bottom Trawl recommendations, IBTS 2010). When large quantities of a species were caught (e.g. sprat), they were randomly sub-sampled by weight, ensuring that at least 30 individual fish length measurements were recorded. Length frequencies were then raised to the total catch, based on the weight sub-sampled. Catch weights were expressed standardised to a 30 min tow. Additional individual weight and length data were collected for sprat and herring in 2009 to allow conversion of acoustic signals to biomass. For beam trawl samples, benthic organisms that might predate on fish eggs and larvae, mainly various species of crab, were removed for stomach content analysis but the entire catch was not identified or weighed. We did not take stomach samples from benthic organisms such as sea urchins and brittlestars as we considered it highly unlikely that they would prey on pelagic fish eggs or larvae.

\section{Predator stomach sampling from trawl catches}

Because of the sensitivity of the TaqMan probe, a key consideration was the avoidance of cross-contamination. Any plaice caught were immediately removed from the catch and transferred to a dedicated measuring station that was not used to process any other species. On each haul a number of negative controls were mixed in with the catch in the hopper. Negative controls consisted of a piece of vinyl disposable glove (representing the stomach) inserted into another glove (representing the fish). Negative controls were processed as for fish samples. After the whole catch had been weighed, sorted and measured, between 20 and 30 individuals of each species (or up to the maximum caught for less abundant species) were selected across the size range. In 2008 both the stomach and hind-guts were dissected out from fish and placed in individual plastic sample bags and immediately frozen to $-20^{\circ} \mathrm{C}$. Based on the TaqMan results from 2008, where all hind-gut samples gave negative results, only the stomachs were preserved in 2009. For organisms such as crabs and squid, the whole animal was frozen. Sampling was discontinued 60 min after the completion of catch sorting to minimise effects of post-mortem degradation. Total time taken for sorting catches ranged from 30 min to $2 \mathrm{~h}$ depending on the size of the catch. Each dissection was performed with clean gloves and instruments. Batches of instruments were decontaminated using Microsol detergent (Anachem) between trawl hauls. In addition to the negative controls inserted into the fish hopper, swabs were taken of the non-plaice processing stations and instruments after cleaning, and were then analysed using the TaqMan probe.

\section{Depth-stratified plankton sampling}

In 2009 a single deployment of a multi-net (BIONESS) system was made. The BIONESS comprises a frame with a $1 \mathrm{~m}$ square opening containing up to ten $300 \mu \mathrm{m}$ mesh opening/closing nets. A SeaBird SBE19 CTD is fitted to record environmental parameters. Filtered volumes were estimated using the manufacturer's software reading data from an external General Oceanics flowmeter and frame tilt-sensor. Because of the relatively shallow water depth $(33 \mathrm{~m})$ only 4 depth strata were sampled. The BIONESS was deployed around 15:00 on 27 February and sampled strata were: 26.4 to $20.6 \mathrm{~m}, 20.6$ to $13.7 \mathrm{~m}, 13.7$ to $9.2 \mathrm{~m}$ and $9.2 \mathrm{~m}$ to the surface. On recovery, nets 
were washed down and samples pre-sorted onboard. Representative examples of the taxa present were frozen individually in well plates for subsequent TaqMan analysis. The remainder of the samples were fixed in $4 \%$ buffered formalin. Samples were subsequently sorted and organisms identified to broad taxonomic categories. Abundance data were converted to numbers $\mathrm{m}^{-3}$ using the estimated volume filtered in each depth-band.

\section{TaqMan analysis of stomach samples and BIONESS samples}

A real-time PCR assay was used to probe potential predators for the presence of plaice DNA. This TaqMan probe, which targets a section of the mitochondrial cytochrome- $\beta$ gene, is highly species-specific and does not cross-react against DNA from a wide range of marine organisms (Albaina et al. 2010). Because the BIONESS samples had been rapidly sorted and frozen at sea (due to concerns about postmortem degradation of DNA in predator guts), it was necessary to check their identifications before processing them for molecular analysis. Frozen BIONESS samples were therefore defrosted in ethanol and identified to the lowest practical taxonomic level. Because there was significant distortion and damage to the bodies of fish larvae we were unable to identify sprat, herring and sandeel larvae to the species level so they were combined as a Clupeidae/Ammodytidae group. Two different extraction methods were used; a CTAB (hexadecyltrimethylammonium bromide) protocol was used for stomach contents of larger predators and a modified salt extraction protocol was used for stomach contents of smaller predators. Stomach contents from fish (excluding sprat) and crabs were partially homogenized in $1.5 \mathrm{ml}$ autoclaved Eppendorf tubes containing $350 \mu \mathrm{l}$ of $2 \%$ CTAB buffer (100mM Tris- $\mathrm{HCl} \mathrm{pH} 8.0 ; 1.4 \mathrm{M} \mathrm{NaCl}$; 20mM EDTA pH 8.0; $2 \% \mathrm{CTAB} ; 0.2 \%$ 2-mercaptoethanol). Sub-samples of the stomach contents of large predators such as lesser spotted dogfish Scyliorhinus canicula were taken, including scraping of the stomach lining. Five microlitres of Proteinase K (Qiagen) was then added and each sample digested overnight at $55^{\circ} \mathrm{C}$. DNA was purified using 2 chloroform-isoamyl alcohol washes followed by sodium acetate precipitation (3M, pH 4.8). Due to their relatively small sizes, whole stomachs from sprat, shrimps, prawns, amphipods, and euphausids and whole organisms from the BIONESS were homogenized in $300 \mu \mathrm{l}$ of extraction buffer $(30 \mathrm{mM}$ Tris- $\mathrm{HCl}$
pH 8.0, 10mM EDTA pH 8.0 and 1\% SDS). Five microlitres of Proteinase K (Qiagen) was then added and each sample digested overnight at $55^{\circ} \mathrm{C}$. DNA was purified following a modified salt protocol (Aljanabi \& Martinez 1997) using $1.2 \mathrm{ml}$ wells in 96well blocks (Starstedt MegaBlock). The DNA was resuspended in $100 \mu \mathrm{l}$ ultrapure $\mathrm{H}_{2} \mathrm{O}$ and stored at $-20^{\circ} \mathrm{C}$. DNA concentrations were quantified using a NanoDrop ${ }^{\circledR}$ ND-1000 spectrophotometer (NanoDrop Technologies).

TaqMan assays were run on a 7900HT Fast RealTime PCR System (Applied Biosystems) following Albaina et al. (2010). Reactions were run in Optical 96-well reaction plates using Optical Adhesive Covers (Applied Biosystems). Each $20 \mu \mathrm{l}$ reaction contained $0.75 \mu \mathrm{l}$ of plaice probe $\left(10 \mu \mathrm{M}_{i}\right.$ VIC reporter $)$, $1.5 \mu \mathrm{l}$ of the PLA-F and PLA-R primers $(10 \mu \mathrm{M}$; Forward and Reverse primers), $10 \mu \mathrm{l}$ of TaqMan Universal PCR Master Mix (NO UNG + ROX passive reference; Applied Biosystems), $1.25 \mu$ tissue culture $\mathrm{H}_{2} \mathrm{O}$ (Sigma), $2.5 \mu \mathrm{l}$ Bovine Serum Albumin (BSA, \#B9001S New England Biolabs) and $2.5 \mu \mathrm{l}$ of extracted DNA. Plates were run under real-time conditions on a single dye layer with 2 no template controls (NTCs) and 2 positive controls (DNA extracted from adult plaice muscle tissue) per 96-well plate. The assay was run using the standard protocol including an initial step of $2 \mathrm{~min}$ at $50^{\circ} \mathrm{C}$ and denaturation at $95^{\circ} \mathrm{C}$ for $10 \mathrm{~min}$, followed by 40 cycles of denaturation at $95^{\circ} \mathrm{C}$ for $15 \mathrm{~s}$ and annealing at $60^{\circ} \mathrm{C}$ for $60 \mathrm{~s}$. Because PCR inhibitors are often co-extracted from crustacea stomachs, samples returning negative TaqMan results were rerun following dilution and addition of BSA the following guidelines in Albaina et al. (2010).

TaqMan results were analysed using the Sequence Detection Software version 2.3 (Applied Biosystems). A positive $\Delta \mathrm{Rn}$ threshold of 0.02 was set for the assay and threshold cycle $(\mathrm{Ct})$ values were computed (Albaina et al. 2010); all amplification curves were also checked visually to remove occasional false positive/negative signals.

\section{RESULTS}

\section{Plankton}

Oceanography and vertically integrated sampling

In 2008 , surface waters were generally cooler inshore (Fig. 2). Vertical profiling showed that the water column was well mixed, with depth integrated 


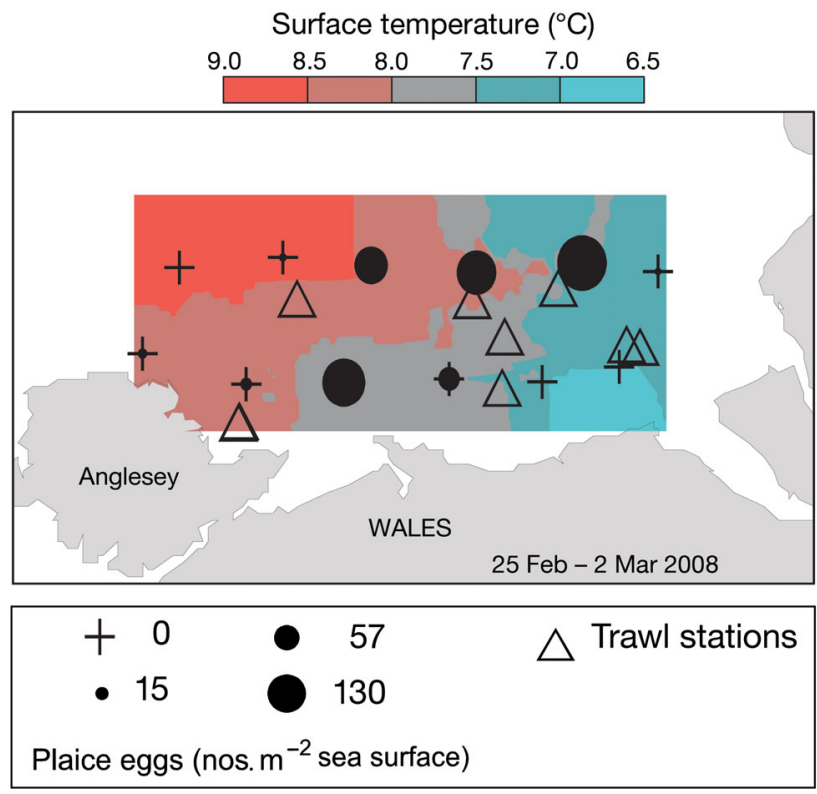

Fig. 2. Sea surface temperature $\left({ }^{\circ} \mathrm{C}\right)$ contoured from Aquatracka data, abundance of plaice eggs (all stages combined, nos. $\mathrm{m}^{-2}$ sea surface) and location of trawl stations in 2008. Plaice egg abundance is proportional to the area of the filled circles, with range and interim values shown in the legend

temperatures ranging from 6.74 to $8.39^{\circ} \mathrm{C}$. Surface to bottom salinity differences were less than 0.6 , except at 1 station, whilst surface salinities ranged from 32.042 to 34.061 . Plaice eggs were concentrated in the north-eastern corner of the sampling grid (Fig. 2) and the spatial distribution of later stage eggs was similar to that of the early stages (data not shown). Plaice larvae were recorded at only 2 stations, the maximum abundance being 1.6 larvae $\mathrm{m}^{-2}$. In 2008, 9 trawl tows were completed using the PHHT. Most trawl stations were located close to the area of high egg abundance but exploratory tows were also conducted to the west of the patch (Fig. 2).

In 2009 , sea surface temperatures were up to $1.7^{\circ} \mathrm{C}$ colder compared with 2008 but the spatial pattern was similar (Fig. 3a,b). The water column was thermally mixed at all stations but surface to bottom salinity differences of up to -1 were noted inshore. Plaice eggs were more evenly distributed across the study area in 2009 (Fig. 3a) compared with 2008, but by the end of the cruise, they had become slightly more concentrated towards the north-western corner (Fig. 3b). In 2009, plaice larvae were found at about half of the plankton stations, and the spatial distribution broadly resembled that of the eggs (Fig. 3a,b). At the start of the cruise a maximum abundance of plaice larvae of $2.3 \mathrm{~m}^{-2}$ was recorded, although this increased slightly to a maximum of 7.9 larvae $\mathrm{m}^{-2}$ in the north-western area by the end of the cruise.

Fish eggs other than plaice were abundant in both years. In 2008, the maximum number of non-plaice eggs was $7178 \mathrm{~m}^{-2}$ and in 2009 it was $1621 \mathrm{~m}^{-2}$. The spatial distribution of plaice and non-plaice eggs tended to be similar (data not shown). The majority of the non-plaice eggs were less than $1.1 \mathrm{~mm}$ in diameter and, although they could not be identified to species, were probably dab Limanda limanda as their larvae are common off the North Wales coast towards the end of March (Bunn \& Fox 2004, Bunn et al. 2004). Other identifiable eggs in the Gulf VII samples included late stage cod Gadus morhua, dragonets (Callionymidae), rocklings, sole Solea solea and sprat, but all of these were present at relatively low abundance. The relative proportion of plaice versus non-plaice eggs was also apparent in the BIONESS samples (Fig. 4).

\section{Depth-stratified BIONESS sampling}

Fish eggs and larvae were the most abundant component of the BIONESS samples and were concentrated towards the surface (Fig. 4). The vast majority of the fish eggs were $<1.1 \mathrm{~mm}$ in diameter and lacked oil globules or other distinguishing characteristics, but Callionymus eggs and a single sandeel egg were caught in the deepest depth strata. In contrast, plaice and sprat eggs were concentrated in the upper strata. Identifiable larvae included sandeel (Ammodytidae), bull-rout Myхосеphalus scorpius, dab, flounder Platichthys flesus, cod, whiting Merlangius merlangus, sea-snail Liparis montagui and plaice. Other larger planktonic organisms caught included various Malacostraca, amphipods and chaetognaths, but these were present at very low densities $\left(<0.3 \mathrm{~m}^{-3}\right)$.

\section{Fishing}

Trawl catches from both years are summarised in Table 1. Herring (length range $8.5-27 \mathrm{~cm}$ ), sprat $(5.5-14.5 \mathrm{~cm})$, whiting $(9-34 \mathrm{~cm})$ and dab $(9-28 \mathrm{~cm})$ were recorded in nearly all of the trawl hauls and dominated the catches in terms of weight. Other frequently caught taxa included squid (Loligo spp.), grey gurnard Eutrigla gurnadus $(8-30 \mathrm{~cm})$, plaice (13-43 cm), poor cod Trisopterus minutus $(8-17 \mathrm{~cm})$, dragonets (11-25 cm), mackerel (19-30 cm), thornback ray Raja clavata $(13-76 \mathrm{~cm})$, flounder (21$41 \mathrm{~cm})$ and lesser spotted dogfish $(44-69 \mathrm{~cm})$. The 

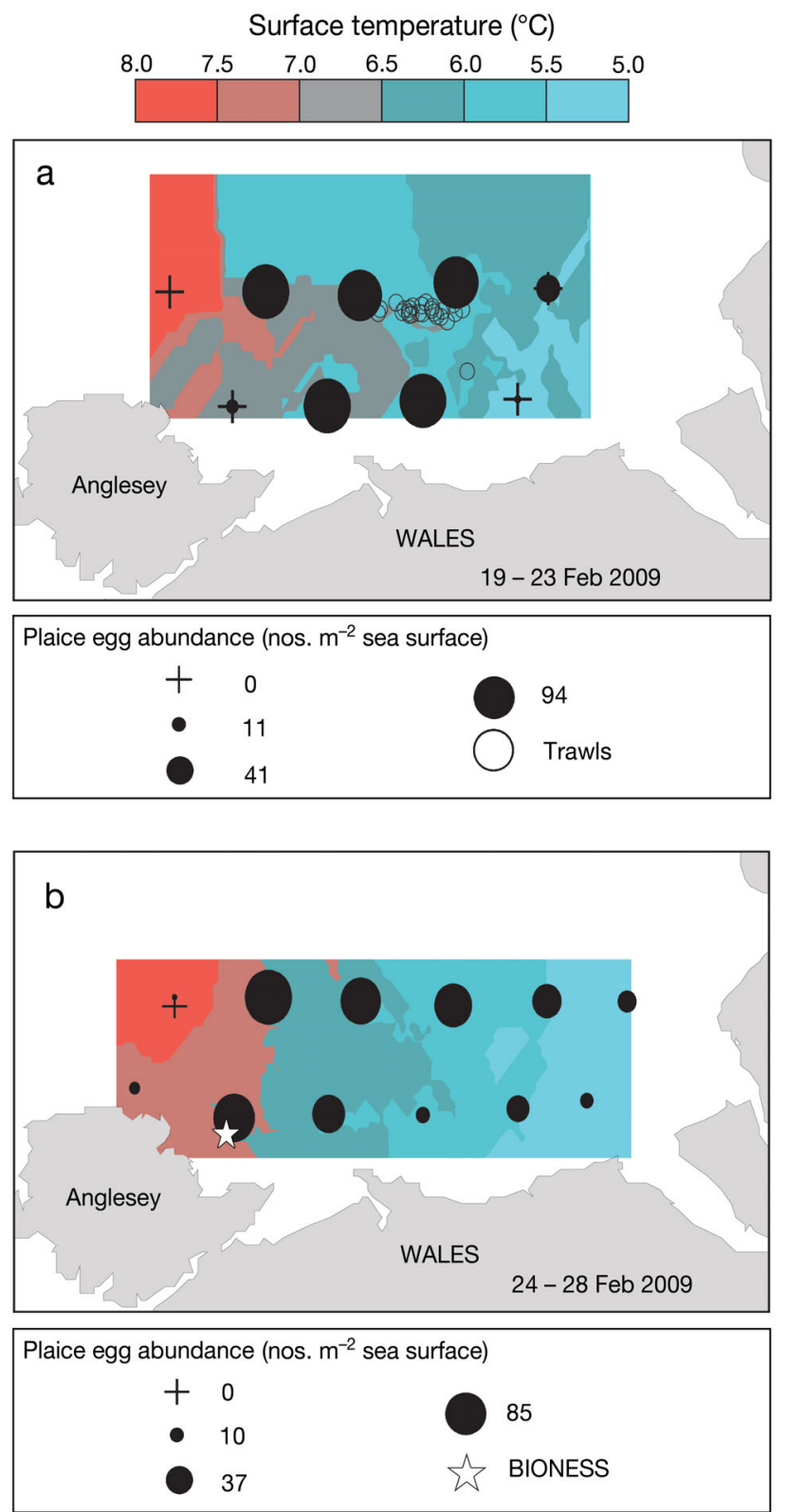

Fig. 3. Sea surface temperature $\left({ }^{\circ} \mathrm{C}\right)$ contoured from Aquatracka data, abundance of plaice eggs (all stages combined, nos. $\mathrm{m}^{-2}$ sea surface) shown at (a) the start of the 2009 cruise with the trawl locations and (b) the end of the 2009 cruise with the Bedford Institute of Oceanography Net and Environmental Sampling System (BIONESS) station. Plaice egg abundance is proportional to the area of the filled circles, with range and interim values shown in the legend

range of species caught in 2009 was smaller than in 2008 , but catch weights of the dominant species, herring and whiting, were higher. In 2009, the range of species caught with the sandeel trawl was larger than with the PHHT but catch weights of herring, sprat and whiting were much lower using this gear.

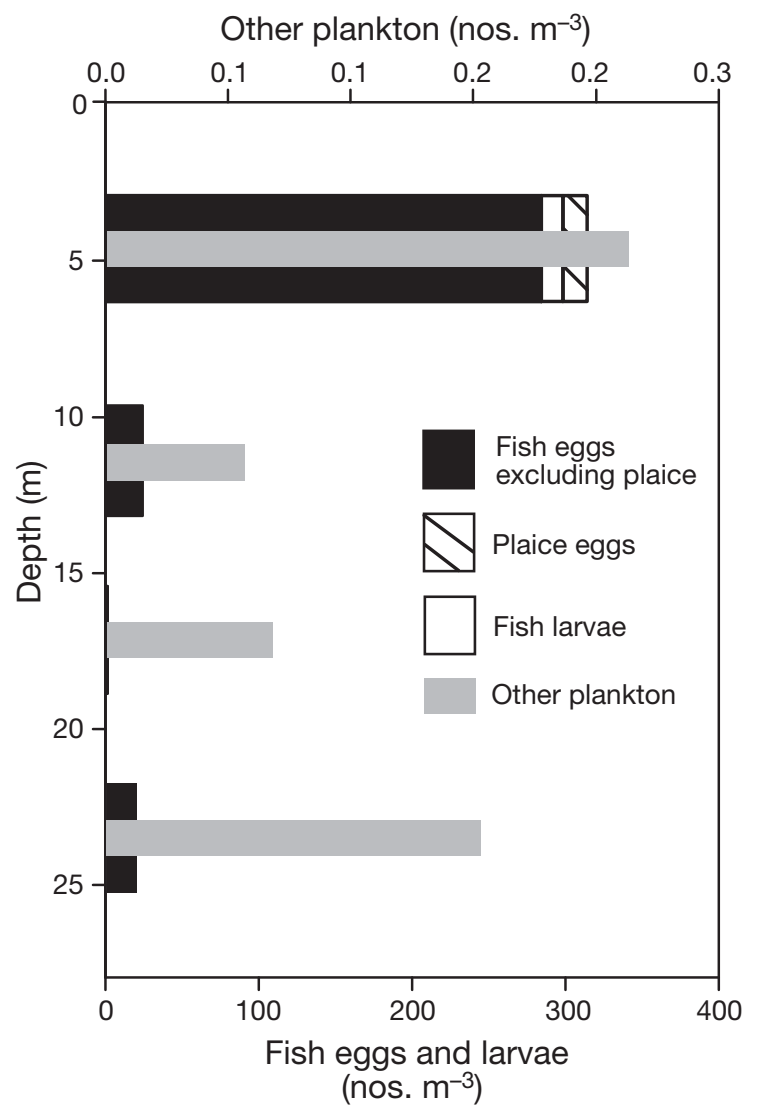

Fig. 4. Vertical distribution of plankton (numbers $\mathrm{m}^{-3}$ ) from the Bedford Institute of Oceanography Net and Environmental Sampling System (BIONESS) deployment

\section{Acoustics}

Trawl catches suggested that the fish community in the water-column consisted of mixed aggregations of herring, sprat and smaller numbers of whiting. There were no apparent diel patterns in species abundance in the trawl data, so results from all trawls were combined and used to partition the acoustic backscatter into relative contributions. Herring and sprat biomass were estimated at $6123 \mathrm{t}\left(93 \times 10^{6}\right.$ ind.) and

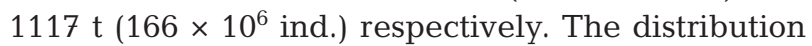
of clupeids showed slightly higher densities in the north of the survey area, although schools were found throughout the area (Fig. 5).

\section{TaqMan analyses}

Summaries of the molecular results are shown in Table 2 . The results were highly consistent between years. In 2008, sprat and herring showed the highest proportion of positive TaqMan responses (45.5 and 
Table 1. Catch summary for the Portuguese high-headline trawl (PHHT) and sandeel trawls, excluding occasional benthic species and the beam trawl tows which were used primarily to provide specimens of benthic organisms. Presence is calculated as percentage of tows in which each species was recorded. Mean catch calculated as mean weights over tow duration

\begin{tabular}{|c|c|c|c|c|c|c|c|}
\hline \multirow[t]{2}{*}{$\begin{array}{l}\text { Common } \\
\text { name }\end{array}$} & \multirow[t]{2}{*}{$\begin{array}{l}\text { Scientific } \\
\text { name }\end{array}$} & \multicolumn{4}{|c|}{$\overline{2008(\mathrm{n}=9)}$ PHHT $\overline{2009(\mathrm{n}=14)}$} & \multicolumn{2}{|c|}{$\begin{array}{c}\text { Sandeel } \\
2009(\mathrm{n}=10)\end{array}$} \\
\hline & & $\begin{array}{l}\text { Presence } \\
(\%)\end{array}$ & $\begin{array}{l}\text { Mean catch } \\
\left(\mathrm{kg} 30 \mathrm{~min}^{-1}\right)\end{array}$ & $\begin{array}{l}\text { Presence } \\
\quad(\%)\end{array}$ & $\begin{array}{l}\text { Mean catch } \\
\left(\mathrm{kg} 30 \mathrm{~min}^{-1}\right)\end{array}$ & $\begin{array}{l}\text { Presence } \\
\quad(\%)\end{array}$ & $\begin{array}{l}\text { Mean catch } \\
\left(\mathrm{kg} 30 \mathrm{~min}^{-1}\right)\end{array}$ \\
\hline Herring & Clupea harengus & 100 & 108.38 & 100 & 532.54 & 40 & 7.16 \\
\hline Sprat & Sprattus sprattus & 100 & 15.58 & 86 & 2.93 & 100 & 1.58 \\
\hline Whiting & Merlangius merlangus & 100 & 55.00 & 100 & 123.80 & 20 & 1.06 \\
\hline Dab & Limanda limanda & 89 & 3.76 & 93 & 42.10 & 40 & 0.25 \\
\hline Squid & Loligo spp. & 78 & 0.19 & 7 & 0.08 & - & - \\
\hline Grey gurnard & Eutrigla gurnadus & 67 & 0.18 & 57 & 0.08 & 10 & 0.01 \\
\hline Plaice & Pleuronectes platessa & 67 & 3.34 & 93 & 3.07 & - & - \\
\hline Poor cod & Trisopterus minutus & 67 & 0.22 & 7 & 0.09 & 10 & 0.03 \\
\hline Dragonets & Callionymidae & 44 & 0.26 & 14 & 0.20 & 10 & 0.53 \\
\hline Mackerel & Scomber scombrus & 44 & 0.43 & 29 & 0.35 & 20 & 0.08 \\
\hline Thornback ray & Raja clavata & 44 & 1.28 & - & - & 10 & 0.48 \\
\hline Flounder & Platichthys flesus & 44 & 2.98 & 79 & 2.00 & 60 & 2.82 \\
\hline Crab & Liocarcinus holsatus & 44 & 0.04 & - & - & 10 & $<0.01$ \\
\hline Lesser spotted dogfish & Scyliorhinus canicula & 44 & 4.40 & 43 & 1.63 & - & - \\
\hline Lemon sole & Microstomus kitt & - & - & 36 & 0.38 & - & - \\
\hline Lesser weever & Trachinus vipera & 33 & 1.65 & - & - & - & - \\
\hline Cod & Gadus morhua & 22 & 1.15 & - & - & - & - \\
\hline Scad & Trachurus trachurus & 22 & 0.43 & - & - & - & - \\
\hline Cuttlefish & Sepiola atlantica & 22 & 0.01 & - & - & 30 & 0.01 \\
\hline Pogge & Agonus cataphractus & 22 & 0.02 & - & - & 10 & 0.01 \\
\hline Bib & Trisopterus luscus & 22 & 0.41 & - & - & - & - \\
\hline Red gurnard & Aspitrigla cuculus & 22 & 1.05 & - & - & - & - \\
\hline Haddock & Melanogrammus aeglefinus & 11 & 0.44 & - & - & - & - \\
\hline Tub gurnard & Triglalucerna & 11 & 0.10 & - & - & - & - \\
\hline Cuttlefish & Sepia officinalis & 11 & 0.05 & - & - & 50 & 0.01 \\
\hline Octopus & Octopoda & 11 & 0.70 & - & - & - & - \\
\hline Swimming crab & Liocarcinus puber & 11 & 0.03 & - & - & - & - \\
\hline Greater sandeel & Hyperoplus lanceolatus & 11 & 0.04 & - & - & 20 & $<0.01$ \\
\hline Raitt's sandeel & Ammodytes marinus & 11 & 0.02 & - & - & 10 & $<0.01$ \\
\hline Brown shrimp & Crangon crangon & 11 & 0.02 & - & - & - & - \\
\hline Pink shrimp & Pandalus sp. & 11 & 0.05 & - & - & 10 & $<0.01$ \\
\hline Five bearded rocking & Ciliatamustela & 11 & 0.12 & - & - & - & - \\
\hline Nurse hound & Scyliorhinus stellaris & 11 & 0.31 & - & - & - & - \\
\hline Pipefish & Syngnathus rostellatus & 11 & 0.09 & - & - & - & - \\
\hline Crystal goby & Crystallogobius linearis & 11 & $<0.01$ & - & - & - & - \\
\hline Tompot blenny & Parablennius gattorugine & - & - & - & - & 10 & 0.47 \\
\hline Gobies & Gobiidae & 11 & $<0.01$ & - & - & 20 & $<0.01$ \\
\hline Three-bearded rockling & Gaidropsarus vulgaris & - & - & - & - & 10 & 0.09 \\
\hline Lumpsucker & Cyclopterus lumpus & - & - & - & - & 10 & 0.04 \\
\hline Thickback sole & Microchirus variegates & - & - & - & - & 10 & 0.03 \\
\hline Scaldfish & Arnoglossus luterna & - & - & - & - & 10 & 0.01 \\
\hline Butterfly blenny & Blennius ocellaris & - & - & 7 & 0.03 & - & - \\
\hline
\end{tabular}

$33.1 \%$ of samples tested respectively), whilst in 2009 the proportions were even higher (85.3 and $96.1 \%$ ). When the percentage of individual sprat and herring yielding a positive TaqMan plaice probe result was plotted against the time of day when the fish were caught, there was no obvious trend (data not shown). Likewise, there was no obvious relationship between proportions showing a positive TaqMan response and the total time taken to process the catch. Mackerel also tested positive although this species was much less numerous than sprat and herring. Whiting were also relatively abundant in both years (Table 1) and around $10 \%$ of the individuals tested positive for plaice DNA. Other species showing low levels of positive response included poor cod and squid. Four species expected to be predominantly demersal but which also gave a low incidence of positive results were red gurnard Aspitrigla cuculus, grey gurnard, dogfish and lesser weever Echiichthys vipera. None of the larger benthic crustacea tested positive (Table 2). 

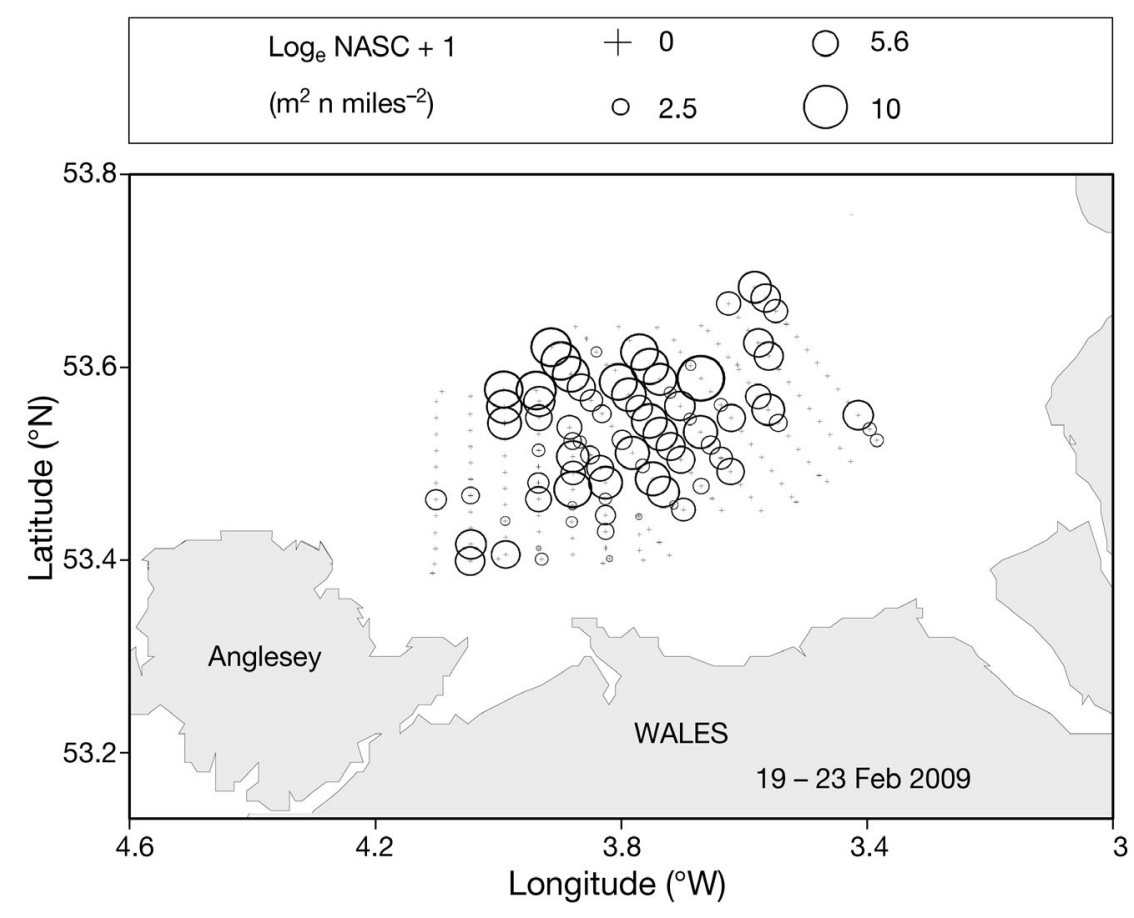

Fig. 5. Acoustically determined clupeid density. Log transformed acoustic signal is proportional to the area of the open circles, with range and interim values shown in the legend. NASC: nautical area backscattering coefficient
From the BIONESS samples, around $13 \%$ of animals tested positive with the TaqMan assay. These positive results were dominated by fish larvae (grouped as mixed Clupeidae and Ammodytidae) which yielded $20 \%$ TaqMan positives, whilst a few Malacostraca and Amphipoda also tested positive (Table 3 ).

\section{DISCUSSION}

Our results demonstrate how the application of modern molecular methods can successfully provide a more holistic description of the predator community preying on a patch of fish eggs/ larvae compared with visual gut content analysis (Brewer et al. 1984). The dominant predators identified were sprat and herring but the TaqMan probe also revealed that whiting, squid, fish larvae (Clupeidae and/or Ammodytidae) and planktonic malacostraca and amphipods were also consuming plaice eggs/lar-

Table 2. Summary of the TaqMan probe results from trawl samples determined from the percentage of stomachs showing a positive response to the plaice probe. Totals tested include the following species, which were collected in low numbers (n $<30$ per species) with no positive TaqMan results: butterfly blenny Blennius ocellaris, bib Trisopterus luscus, cod Gadus morhua, crab Liocarcinus depurator, common dragonet Callionymus lyra, Dover sole Solea solea, edible crab Cancer pagurus, gobies Gobiidae, greater weever Trachinus draco, harbour crab Liocarcinus depurator, lemon sole Microstomus kitt, lumpsucker Cyclopterus lumpus, masked crab Corystes cassivelaunus, pogge Agonus cataphractus, prawn Nephrops norvegicus, rockling Ciliata mustela, sandeel Ammodytes marinus, scaldfish Arnoglossus laterna, scad Trachurus trachurus, solenette Buglossidium luteum, spotted ray Raja montagui, thickback sole Microchirus variegatus, thornback ray Raja clavata, tub gurnard Trigla lucerna, and velvet crab Necora puber

\begin{tabular}{|c|c|c|c|c|c|c|c|}
\hline \multirow[t]{2}{*}{ Common name } & \multirow{2}{*}{$\begin{array}{l}\text { Scientific } \\
\text { name }\end{array}$} & \multicolumn{2}{|c|}{$-2008-$} & \multicolumn{2}{|c|}{$2009 \square$} & \multicolumn{2}{|c|}{$\ldots$} \\
\hline & & $\mathrm{n}$ & $\%$ positive & $\mathrm{n}$ & $\%$ positive & $\mathrm{n}$ & $\%$ positive \\
\hline Herring & Clupea harengus & 159 & 33 & 383 & 96 & 542 & 77 \\
\hline Sprat & Sprattus sprattus & 173 & 45 & 537 & 85 & 710 & 75 \\
\hline Mackerel & Scomber scombrus & 12 & 33 & 17 & 6 & 29 & 17 \\
\hline Poor cod & Trisopterus minutus & 23 & 13 & 10 & 20 & 33 & 15 \\
\hline Red gurnard & Aspitrigla cuculus & 14 & 20 & - & - & 14 & 20 \\
\hline Whiting & Melangius merlangus & 75 & 11 & 293 & 11 & 368 & 11 \\
\hline Squid & Loligo spp. & 25 & 8 & 1 & 0 & 26 & 8 \\
\hline Lesser weever & Trachinus vipera & 13 & 8 & 22 & 0 & 35 & 8 \\
\hline Lesser spotted dogfish & Scyliorhinus canicula & 23 & 4 & 11 & 0 & 34 & 3 \\
\hline Grey gurnard & Eutrigla gurnadus & 26 & 0 & 37 & 3 & 63 & 2 \\
\hline Dab & Limanda limanda & 55 & 0 & 181 & 0 & 236 & 0 \\
\hline Crab & Liocarcinus holsatus & 15 & 0 & 149 & 0 & 164 & 0 \\
\hline Flounder & Platichthys flesus & 23 & 0 & 63 & 0 & 86 & 0 \\
\hline Brown shrimp & Crangon crangon & - & - & 59 & 0 & 59 & 0 \\
\hline Cuttlefish & Sepiola atlantica & 1 & 0 & 47 & 0 & 48 & 0 \\
\hline Hermit crabs & Pagurus spp. & - & - & 45 & 0 & 45 & 0 \\
\hline Negative controls & & 25 & 0 & 78 & 0 & 103 & 0 \\
\hline Total tested & & 748 & & 2154 & & 2909 & \\
\hline
\end{tabular}


Table 3. TaqMan results from the Bedford Institute of Oceanography Net and Environmental Sampling System (BIONESS) depth-stratified sampling. n: no. of individuals

\begin{tabular}{|lccc|}
\hline Taxa & $\begin{array}{c}\text { Total } \\
\text { tested } \\
\text { (n) }\end{array}$ & $\begin{array}{c}\text { Positive TaqMan } \\
(\mathrm{n})\end{array}$ & $(\%)$ \\
\hline Fish larvae & 348 & 68 & 19.5 \\
$\quad$ (Clupeidae \& Ammodytidae) & & & \\
Malacostraca & 138 & 4 & 2.8 \\
Amphipoda & 31 & 1 & 3.2 \\
Chaetognatha & 21 & 0 & 0 \\
Total & 567 & 73 & 12.9 \\
\hline
\end{tabular}

vae. These findings extend results from previous studies which reported on a more restricted range of predators (Daan 1976, Ellis \& Nash 1997).

\section{Clupeids as fish egg predators}

Previous studies have implicated sprat and herring as important consumers of fish eggs (Daan 1976, Pommeranz 1981, Ellis \& Nash 1997, Köster \& Möllmann 2000, Köster et al. 2001, Möllmann et al. 2004, Segers et al. 2007). Ellis \& Nash (1997) found that 75 to $97 \%$ of sprat stomachs sampled from a small plaice spawning ground off the Isle of Man contained plaice eggs; for herring, the proportions varied from 25 to $48 \%$. TaqMan data from the present study yielded similar values for sprat but higher values for herring (96\% of herring stomachs testing positive in 2009). Combined with the potential for individual sprat and herring to consume large numbers of eggs (Ellis \& Nash 1997 , Plirú et al. 2011), the present results support the idea that clupeids may be the most important predators of plaice eggs/larvae in the Irish Sea. The acoustics surveys also revealed the presence of several schools of sprat and herring in the study area and their spatial distribution broadly corresponded with the abundance of fish eggs. Although this suggests that clupeids might be targeting egg patches, further research is needed to determine whether clupeid shoals remain within egg patches over extended periods and whether they switch feeding modes when eggs are abundant (Batty et al. 1986, Sims et al. 2008).

A number of other species that are known to feed in the water column, including mackerel, whiting, poor cod and squid, were shown to be consuming plaice eggs/larvae in the present study. As far as we are aware, these species have not been previously identified as predators on the early stages of plaice. Harding et al. (1978) did, however, report the presence of plaice eggs in the stomachs of grey gurnard.
Except for whiting, the abundance of these non-clupeid species off the North Wales coast during the present study was low, supporting the idea that sprat and herring were the dominant consumers (Table 1).

The abundance of other potential predators in the plankton was very low (Fig. 4), but the BIONESS samples showed a surprising number of positive responses. In particular, fish larvae appeared to be consuming plaice eggs/larvae. Because of damage to the specimens prior to molecular analysis, these larvae could not be identified to species level and were grouped as mixed Clupeidae/Ammodytidae. Given the low abundance of adult sand-eel in the area (Table 1), it is probable that the majority of these larvae were actually sprat. The relatively high numbers of positive TaqMan reactions from non-plaice fish larvae are unlikely to be due to contamination, since very low numbers of other organisms tested from the BIONESS samples gave positive reactions. Gelatinous predators are also often cited as major consumers of fish eggs and larvae (Purcell \& Arai 2001), but in the present study gelatinous predators were not common (Madin et al. 1996). Populations of species such as Aurelia aurita and Cyanea capitella usually peak in late summer/autumn in the Irish Sea (Houghton et al. 2007) and predation pressure from these organisms should be relatively low early in the year (Purcell \& Arai 2001).

\section{Use of molecular probes in marine predation studies}

Using a state-of-the-art molecular approach we were able to rapidly screen nearly 3000 stomach contents and 550 planktonic organisms as potential predators of plaice eggs/larvae. This enabled confirmation of the importance of sprat and herring as consumers of fish eggs but also identified additional predators such as whiting, poor cod, red and grey gurnard and fish larvae. Despite the difficulties of sorting trawl catches, cross-contamination between samples did not appear to be a significant problem, as evidenced by non-reactivity of the negative controls.

Dependent on development stage and temperature, the TaqMan probe has a T90 (the length of time after ingestion that target DNA can be detected in $>90 \%$ of the predators tested) of between 4 and $5 \mathrm{~h}$ (Albaina et al. 2010, Hunter et al. 2012). Field sampling of predators should thus be undertaken regularly every $4 \mathrm{~h}$ (for predators showing no diel feeding rhythms), or samples should be collected within $4 \mathrm{~h}$ 
of peak feeding (for predators showing diel consumption patterns). By fishing every $4 \mathrm{~h}$ over several days, detection rates in the present study should have been in the region of $90 \%$ or better at some point during each $24 \mathrm{~h}$ period. Degradation of prey DNA in predator stomachs post-capture might result from post-mortem $\mathrm{pH}$ changes and protease action. Unfortunately, we are not aware of any studies which provide data on how rapidly this can occur so the $2 \mathrm{~h}$ limit we used, whilst somewhat arbitrary, seemed a reasonable compromise between allowing full sorting and sampling of the catch and this risk. For sprat and herring, more than $85 \%$ of individuals tested positive, regardless of the time of day of sampling, supporting high detection efficiency for the assay and suggesting that degradation of target DNA was not a major problem.

Regurgitation of prey is known to be a particular problem when sampling teleost predators using trawls and can lead to under-estimation of feeding rates (Bowman 1986). It is usually recommended to use tows that are as short as possible to minimise this problem. However, the molecular approach to stomach content analysis may be less sensitive to this problem, since the TaqMan probe has been shown to be capable of detecting residual prey DNA, even when there are no remaining visible signs (Hunter et al. 2012). The opposite problem, that other organisms might consume regurgitated material whilst in the trawl or plankton nets, leading to over-estimation of feeding rates, cannot be dismissed entirely, although for the trawl it is likely that regurgitated material would be rapidly flushed out of the net during towing because of the mesh size of the cod-end. It is feasible that feeding incidence in the BIONESS samples was over-estimated because of this problem (Hunter 1984).

Because of their size and thick wall, plaice eggs and their shells can often be identified in fish stomachs (Ellis \& Nash 1997, Plirú et al. 2011). However, eggs of other species cannot be so readily identified; for example cod, haddock Melanogrammus aeglefinus and whiting eggs cannot be visually distinguished until the late developmental stages (Fox et al. 2008). For studies targeting predation on species with visually indistinguishable eggs, a visual inspection of predator stomach contents will be unable to assign prey consumed to species level. The application of molecular tools to unambiguously identify fish eggs in the water column (Fox et al. 2008, Goodsir et al. 2008) and in predator guts (present paper) can solve some of these problems. On the other hand, the molecular approach cannot yet provide information on the number of eggs or larvae consumed, nor on the developmental stages of the prey.

The molecular approach is also a powerful tool for screening predators that macerate their prey (Theilacker et al. 1993). For example, TaqMan results from the BIONESS indicated that some amphipods and malacostraca were consuming plaice eggs/larvae. Euphausiids have also been reported to consume fish eggs and larvae (Bailey et al. 1993) but they were not abundant in the egg patch investigated. Euphausiids are much more common in the deeper parts of the western Irish Sea (Mauchline 1984) where they could be more important as predators of fish eggs, since these areas are also adjacent to fish spawning grounds (Fox et al. 2000a).

Finally, because the TaqMan method is so sensitive, it may detect secondary predation, e.g. the few positive TaqMan results from dogfish stomachs in this study. The diet of dogfish in the Irish Sea is known to include herring (Lyle 1983), which are themselves important consumers of plaice eggs as shown in the present study and by Ellis \& Nash (1997).

\section{Relevance to previous studies on predation on fish eggs and larvae}

Our results support and extend data from the southern North Sea (Daan 1976, Segers et al. 2007) and the Irish Sea (Ellis \& Nash 1997), where sprat and herring were reported to be important consumers of plaice eggs. Although sprat and herring both feed predominantly on copepods, they will switch to alternate prey when copepods are scarce (Daan 1976, Segers et al. 2007). In UK waters, plaice complete spawning well before the spring increase in zooplankton (Simpson 1959a,b, Fox et al. 2000a, 2007). This was reflected in the present study where eggs of plaice, and other fish, dominated the plankton (Fig. 4). Fish eggs may thus provide a valuable pulse of consumable biomass to pelagic predators early in the year when there is little alternative food available.

Although year-class strength in North Sea plaice appears broadly predictable from the abundance of late-stage eggs (Bannister et al. 1974, Brander \& Houghton 1982), further research is required to examine whether this holds true for other plaice stocks and can be linked to levels of egg predation. A further area which requires study is the possible effects of inter-annual changes in water temperature on the activity and feeding rates of egg and larval predators since this could, potentially, explain the observation of a negative correlation between sea 
temperatures during late winter and early spring and subsequent recruitment success in several plaice stocks (Fox et al. 2000b). Across a wide range of temperatures, Pepin (1991) found that increased instantaneous mortality was offset by increased development rates so that resulting total mortality across the egg stage was less temperature-sensitive compared with absolute rates. However, there was considerable scatter about this general relationship so that within regions, temperature might still have an impact on overall survival. Results from Daan (1976), Ellis \& Nash (1997) and Plirú et al. (2011) suggest that the abundance, distribution and feeding intensity of sprat and herring may be especially important in this respect. Despite several examples where clupeids are thought to play a key role in controlling recruitment of other fish (Cushing 1980, Speirs et al. 2010, Frank et al. 2011), firm links have only been established in the Baltic (Köster et al. 2001, Lindegren et al. 2009) and Barents Sea (Pedersen et al. 2009). In areas such as the North and Irish Seas, the abundance and distribution of herring is relatively well monitored on an annual basis. In contrast, much less is known about changes in sprat abundance and distribution (ICES 2010). Because of their apparent importance as consumers of the early life stages of other species, improvements in monitoring of sprat in particular will probably be required if ecosystembased approaches to managing marine fish stocks are to succeed (Köster \& Möllmann 2000, Kelly et al. 2006, Segers et al. 2007, Lindegren et al. 2009, Speirs et al. 2010, Frank et al. 2011).

Acknowledgements. We thank the officers and crew of the RV 'Endeavour' and the staff of the Centre for Environment, Fisheries \& Aquaculture Science (Cefas) plankton sorting team whose hard work made this research possible. Probe development as well as the research discussed in this paper was funded by Department for Environment, Food and Rural Affairs (Defra) contracts M0432 PREDATE and M1102 MEMFISH. Whilst writing the paper, C.J.F. was supported by the Natural Environment Research Council (NERC) Oceans2025 program WP4, Predators and prey.

\section{LITERATURE CITED}

Albaina A, Fox CJ, Taylor N, Hunter E, Maillard M, Taylor MI (2010) A TaqMan real-time PCR based assay targeting plaice (Pleuronectes platessa L.) DNA to detect predation by the brown shrimp (Crangon crangon L.) and the shore crab (Carcinus maenas L.) - assay development and validation. J Exp Mar Biol Ecol 391:178-189

> Albaina A, Taylor MI, Fox CJ (2012) Molecular detection of plaice remains in the stomachs of potential predators on a flatfish nursery ground. Mar Ecol Prog Ser 444:223-238
Aljanabi SM, Martinez I (1997) Universal and rapid saltextraction of high quality genomic DNA for PCR-based techniques. Nucleic Acids Res 25:4692-4693

> Bailey KM, Brodeur RD, Merati N, Yoklavich MM (1993) Predation on walleye pollack (Theragra chalcogramma) eggs and yolk-sac larvae by pelagic crustacean invertebrates in the western Gulf of Alaska. Fish Oceanogr 2: 30-39

Bannister RCA, Harding D, Lockwood SJ (1974) Larval mortality and subsequent year-class strength in the plaice (Pleuronectes platessa L.). In: Blaxter JHS (ed) The early life history of fish, Vol. 1. Proc Int Symp Dunstaffnage Mar Res Lab, Oban, Scotland. Springer-Verlag, Berlin, p 21-37

> Batty RS, Blaxter JHS, Libby DA (1986) Herring (Clupea harengus) filter-feeding in the dark. Mar Biol 91:371-375

> Bowman R (1986) Effect of regurgitation on stomach content data of marine fishes. Environ Biol Fishes 16:171-181

Brander K, Houghton RG (1982) Predicting the recruitment of North Sea plaice from egg surveys. ICES CM 1982/G: $5, \mathrm{p} 1-3$

> Brander KM, Milligan SP, Nichols JH (1993) Flume tank experiments to estimate the volume filtered by highspeed plankton samplers and to assess the effect of net clogging. J Plankton Res 15:385-401

Brewer GD, Kleppel GS, Dempsey M (1984) Apparent predation on ichthyoplankton by zooplankton and fishes in nearshore waters of southern California. Mar Biol 80: $17-28$

Browman HI (2003) Assessing the impacts of solar ultraviolet radiation on the early life stages of crustacean zooplankton and ichthyoplankton in marine coastal systems. Estuaries 26:30-39

Bunn N, Fox CJ (2004) Spring plankton surveys of the Irish Sea in 2000: hydrography and the distribution of fish eggs and larvae. Sci Ser Data Rep No. 41. Centre for Environment, Fisheries and Aquaculture Science, Lowestoft

Bunn NA, Fox CJ, Webb T (2000) A literature review of studies on fish egg mortality: implications for the estimation of spawning stock biomass by the annual egg production method. Sci Ser Tech Rep 111. Centre for Environment, Fisheries and Aquaculture Science, Lowestoft

Bunn N, Fox CJ, Nash RDM (2004) Spring plankton surveys of the eastern Irish Sea in 2001, 2002 and 2003: hydrography and the distribution of fish eggs and larvae. Sci Ser Data Report No. 42. Centre for Environment, Fisheries and Aquaculture Science, Lowestoft

> Cameron P, von Westernhagen H (1997) Malformation rates in embryos of North Sea fishes in 1991 and 1992. Mar Pollut Bull 34:129-134

> Cushing DH (1980) The decline of the herring stocks and the gadoid outburst. J Cons Int Explor Mer 39:70-81

Daan N (1976) Some preliminary investigations into predation on fish eggs and larvae in the southern North Sea. ICES CM 1976(L):15, p 1-5

> Deagle BE, Kirkwood R, Jarman SN (2009) Analysis of Australian fur seal diet by pyrosequencing prey DNA in faeces. Mol Ecol 18:2022-2038

Ellis T, Nash RDM (1997) Predation by sprat and herring on pelagic fish eggs in a plaice spawning area in the Irish Sea. J Fish Biol 50:1195-1202

> Fässler SMM, Payne MR, Brunel T, Dickey-Collas M (2011) Does larval mortality influence population dynamics? An analysis of North Sea herring (Clupea harengus) time series. Fish Oceanogr 20:530-543 
Feigenbaum DL, Maris RC (1984) Feeding in the chaetognatha. Oceanogr Mar Biol Annu Rev 22:343-392

Folkvord A (1993) Prey recognition in stomachs of cannibalistic juvenile cod (Gadus morhua L.). Sarsia 78:97-100

- Foote KG (1987) Fish target strengths for use in echo integrator surveys. J Acoust Soc Am 82:981-987

Foote KG, Knudsen HP, Vestnes G, MacLennan DN, Simmonds EJ (1987) Calibration of acoustic instruments for fish density estimation: a practical guide. Report No. 144. ICES, Copenhagen

Fox CJ, O'Brien CM, Dickey-Collas M, Nash RDM (2000a) Patterns in the spawning of cod (Gadus morhua L.), sole (Solea solea L.) and plaice (Pleuronectes platessa L.) in the Irish Sea as determined by generalized additive modelling. Fish Oceanogr 9:33-49

Fox CJ, Planque BP, Darby CD (2000b) Synchrony in the recruitment time-series of plaice (Pleuronectes platessa L.) around the United Kingdom and the influence of sea temperature. J Sea Res 44:159-168

> Fox CJ, Geffen AJ, Taylor N, Davison P, Rossetti H, Nash RDM (2007) Birth-date selection in early life stages of plaice Pleuronectes platessa in the eastern Irish Sea (British Isles). Mar Ecol Prog Ser 345:255-269

Fox CJ, Taylor M, Dickey-Collas M, Fossum P and others (2008) Mapping the spawning grounds of North Sea cod (Gadus morhua) by direct and indirect means. Proc R Soc B Biol Sci 275:1543-1548

> Frank KT, Petrie B, Fisher JAD, Leggett WC (2011) Transient dynamics of an altered large marine ecosystem. Nature.

Goodsir F, Armstrong MJ, Witthames PR, Maxwell DL, Fox CJ (2008) The use of species-specific TaqMan probes for identifying early stage gadoid eggs following formaldehyde fixation. ICES J Mar Sci 65:1573-1577

Harding D, Nichols JH, Tungate DS (1978) The spawning of plaice (Pleuronectes platessa L.) in the southern North Sea and English Channel. Rapp P-V Réun Cons Int Explor Mer 172:102-113

Heath MR (1992) Field investigations of the early life stages of marine fish. Adv Mar Biol 28:1-174

Hjort J (1914) Fluctuations in the great fisheries of northern Europe viewed in the light of biological research. Rapp P-V Réun Cons Int Explor Mer 20:1-228

Houde ED (2002) Mortality. In: Fuiman LA, Werner RG (eds) Fishery science, the unique contributions of early life stages. Blackwell Science, Oxford, p 64-87

Houde ED (2008) Emerging from Hjort's shadow. J Northwest Atl Fish Sci 41:53-70

Houghton JDR, Doyle TK, Davenport J, Lilley MKS, Wilson RP, Hays GC (2007) Stranding events provide indirect insights into the seasonality and persistence of jellyfish medusae (Cnidaria: Scyphozoa). Hydrobiologia 589: $1-13$

Hunter JR (1981) Feeding ecology and predation of marine fish larvae. In: Lasker R (ed) Marine fish larvae: morphology, ecology and relation to fisheries. Washington Sea Grant, Seattle, WA, p 33-77

Hunter JR (1984) Inferences regarding predation on the early life stages of cod and other fishes. In: Dahl E, Danielssen DS, Moksness E, Solemdal P (eds) The propagation of cod Gadus morhua L. Flødevigen rapportser 1: 533-562

Hunter JR, Kimbrell CA (1980) Egg cannibalism in the northern anchovy, Engraulis mordax. Fish Bull 78: $811-816$
Hunter E, Taylor N, Fox CJ, Maillard M, Taylor MI (2012) Effectiveness of TaqMan probes for detection of fish eggs and larvae in the stomach contents of a teleost predator. J Fish Biol 81:320-328

> Huwer B, Clemmesen C, Grønkjær P, Köster FW (2011) Vertical distribution and growth performance of Baltic cod larvae-field evidence for starvation-induced recruitment regulation during the larval stage? Prog Oceanogr 91:382-396

IBTS (International Bottom Trawl Survey) (2010) Manual for the International Bottom Trawl Surveys revision VIII. ICES, Copenhagen

ICES (International Council for the Exploration of the Sea) (2010) Report of the Herring Assessment Working Group (HAWG) for the area south of $62^{\circ} \mathrm{N}$. ICES CM 2010: ACOM:06, ICES, Copenhagen

Kelly CJ, Codling EA, Rogan E (2006) The Irish Sea cod recovery plan: some lessons learned. ICES J Mar Sci 63: 600-610

Klumpp DW, von Westernhagen H (1995) Biological effects of pollutants in Australian tropical coastal waters: embryonic malformations and chromosomal aberrations in developing fish eggs. Mar Pollut Bull 30: 158-165

Korneliussen RJ, Diner N, Ona E, Berger L, Fernandes PG (2008) Proposals for the collection of multifrequency acoustic data. ICES J Mar Sci 65:982-994

Köster FW, Möllmann C (2000) Trophodynamic control by clupeid predators on recruitment success in Baltic cod? ICES J Mar Sci 57:310-323

Köster FW, Hinrichsen HH, St. John MA, Schnack D, MacKenzie BR, Tomkiewicz J, Plikshs M (2001) Developing Baltic cod recruitment models. II. Incorporation of environmental variability and species interaction. Can J Fish Aquat Sci 58:1534-1556

Krautz MC, González M, Castro LR (2003) Detection of anchoveta (Engraulis ringens Jenyns 1842) eggs in euphausiid diets using immunoassays (ELISA). J Exp Mar Biol Ecol 294:27-39

> Krautz MC, Castro LR, González M (2007) Interaction of two key pelagic species in the Humboldt Current: euphausiid predation on anchoveta eggs estimated by immunoassays. Mar Ecol Prog Ser 335:175-185

Lindegren M, Möllmann C, Nielsen A, Stenseth NC (2009) Preventing the collapse of the Baltic cod stock through an ecosystem-based management approach. Proc Natl Acad Sci USA 106:14722-14727

- Lyle JM (1983) Food and feeding habits of the lesser spotted dogfish, Scyliorhinus canicula (L.), in Isle of Man waters. J Fish Biol 23:725-737

Lynam CP, Heath MR, Hay SJ, Brierley AS (2005) Evidence for impacts by jellyfish on North Sea herring recruitment. Mar Ecol Prog Ser 298:157-167

Madin LP, Bollens SM, Horgan E, Butler M and others (1996) Voracious planktonic hydroids: unexpected predatory impact on a coastal marine ecosystem. Deep-Sea Res II 43:1823-13298

Mauchline J (1984) Euphausiid, Stomatopod and Leptostracan crustaceans: keys and notes for the identification of the species, Vol 30. Linnean Society of London, Estuarine and Brackish-water Sciences Association, E. J. Brill, London

McGurk MD (1986) Natural mortality of marine pelagic fish eggs and larvae: role of spatial patchiness. Mar Ecol Prog Ser 34:227-242 
Meneses I, Vendrell C, Stratoudakis Y (2003) Mackerel (Scomber scombrus) eggs parasitized by Ichthyodinium chabelardi in the north-east Atlantic: an overlooked source of mortality. J Plankton Res 25:1177-1181

Möllmann C, Kornilovs G, Fetter M, Köster FW (2004) Feeding ecology of central Baltic Sea herring and sprat. J Fish Biol 65:1563-1581

- Myers RA, Cadigan NG (1993) Density-dependent juvenile mortality in marine demersal fish. Can J Fish Aquat Sci 50:1576-1590

Nash RDM, Dickey-Collas M, Milligan SP (1998) Descriptions of the Gulf VII/PRO-NET and MAFF/Guildline unencased high-speed plankton samplers. J Plankton Res 20:1915-1926

> Nejstgaard JC, Frischer ME, Raule CL, Gruebel R, Kohlberg KE, Verity PG (2003) Molecular detection of algal prey in copepod guts and fecal pellets. Limnol Oceanogr Methods 1:29-38

Passmore AJ, Jarman SN, Swadling KM, Kawaguchi S, McMinn A, Nicol S (2006) DNA as a dietary biomarker in Antarctic krill, Euphausia superba. Mar Biotechnol 8:686-696

$>$ Pedersen OP, Pedersen T, Tande KS, Slagstad D (2009) Integrating spatial and temporal mortality from herring on capelin larvae: a study in the Barents Sea. ICES J Mar Sci 66:2183-2194

> Pepin P (1991) Effect of temperature and size on development, mortality, and survival rates of the pelagic early life history stages of marine fish. Can J Fish Aquat Sci 48: 503-518

Platt T, Sathyendranath S, Fuentes-Yaco C (2007) Biological oceanography and fisheries management: perspective after 10 years. ICES J Mar Sci 64:863-869

Plirú A, van der Kooij J, Engelhard GH, Fox CJ, Milligan SP, Hunter E (2011) Is recruitment of plaice in the Irish Sea constrained by predation of eggs by sprat? Report No. ICES CM 2011/H:33

Pommeranz T (1981) Observations on the predation of herring (Clupea harengus L.) and sprat (Sprattus sprattus L.) on fish eggs and larvae in the southern North Sea. Rapp P-V Réun Cons Int Explor Mer 178:402-404

Purcell JE (1985) Predation on fish eggs and larvae by pelagic cnidarians and ctenophores. Bull Mar Sci 37:739-755

Purcell JE, Arai MN (2001) Interactions of pelagic cnidarians and ctenophores with fish: a review. Hydrobiologia 451: 27-44

Robinson BJ (1983) In situ measurements of the target strength of pelagic fishes. FAO Fisheries Report No. 300. Food and Agriculture Organisation of the United Nations, Rome, p 99-103

Rosel PE, Kocher TD (2002) DNA-based identification of larval cod in stomach contents of predatory fishes. J Exp Mar Biol Ecol 267:75-88

Russell FS (1976) The eggs and planktonic stages of British marine fishes. Academic Press, London

Editorial responsibility: Edward Durbin, Narragansett, Rhode Island, USA
Segers FHID, Dickey-Collas M, Rijnsdorp AD (2007) Prey selection by North Sea herring (Clupea harengus), with special reference to fish eggs. ICES J Mar Sci 64: 60-68

Simpson AC (1959a) The spawning of the plaice (Pleuronectes platessa) in the Irish Sea. Fisheries Investigations Series II, Vol. XXII, No. 8. Ministry of Agriculture, Fisheries and Food, Lowestoft

Simpson AC (1959b) The spawning of the plaice (Pleuronectes platessa) in the North Sea. Fisheries Investigations Series II, Vol. XXII, No. 7. Ministry of Agriculture, Fisheries and Food, Lowestoft

Sims DW, Southall EJ, Humphries NE, Hays GC and others (2008) Scaling laws of marine predator search behaviour. Nature 451:1098-1102

Sissenwine MP (1984) Why do fish populations vary? In: May RM (ed) Exploitation of marine communities. Springer-Verlag, Berlin, p 59-94

Speirs DC, Guirey EJ, Gurney WSC, Heath MR (2010) A length-structured partial ecosystem model for cod in the North Sea. Fish Res 106:474-494

- Suzuki N, Hoshino K, Murakami K, Takeyama H, Chow S (2008) Molecular diet analysis of phyllosoma larvae of the Japanese spiny lobster Panulirus japonicus (Decapoda: Crustacea). Mar Biotechnol 10:49-55

Symondson WOC (2002) Molecular identification of prey in predator diets. Mol Ecol 11:627-641

Taylor DL (2004) Immunological detection of winter flounder (Pseudopleuronectes americanus) eggs and juveniles in the stomach contents of crustacean predators. J Exp Mar Biol Ecol 301:55-73

Taylor DL, Danila DJ (2005) Predation on winter flounder (Pseudopleuronectes americanus) eggs by the sand shrimp (Crangon septemspinosa). Can J Fish Aquat Sci 62:1611-1625

Taylor MI, Fox CJ, Rico I, Rico C (2002) Species-specific TaqMan probes for simultaneous identification of cod (Gadus morhua L.), haddock (Melanogrammus aeglefinus L.) and whiting (Merlangius merlangus L.). Mol Ecol Notes 2:599-601

- Theilacker GH, Kimball AS, Trimmer JS (1986) Use of an ELISPOT immunoassay to detect euphausiid predation on larval anchovy. Mar Ecol Prog Ser 30:127-131

Theilacker GH, Lo NCH, Townsend AW (1993) An immunochemical approach to quantifying predation by euphausiids on the early stages of anchovy. Mar Ecol Prog Ser 92:35-50

> Vestheim H, Edvardsen B, Kaartvedt S (2005) Assessing feeding of a carnivorous copepod using species-specific PCR. Mar Biol 147:381-385

Zhang T, Bailey KM, Chan KS (2010) Recruitment forecast models for walleye pollock Theragra chalcogramma finetuned from juvenile survey data, predator abundance and environmental phase shifts. Mar Ecol Prog Ser 417: 237-248

Submitted: November 1, 2011; Accepted: April 5, 2012 Proofs received from author(s): July 6, 2012 